\title{
Map, Figures, and Tables
}

Map

I. Map of Huizhou in the Late Imperial Yangzi

River Delta.

xiv

Figures

I.I Mountainous Huizhou (I725).

I.2 The Lineage Temple of the Yingzhou Hus, Jixi

(late Ming).

I.3 The interior courtyard of the Lineage Temple of

the Yingzhou Hus, Jixi (late Ming).

I.4 The lineage temple of the Tangyue Baos, Shexian

(late eighteenth century).

I.5 Seven memorial archways honoring loyal officials, filial sons, and chaste widows of the Tangyue Baos, Shexian (Ming and Qing).

I.6 A late-Ming illustration of a freestanding ancestral hall.

I.7 A High-Qing illustration of a freestanding ancestral hall.

I.8 The model of an ancestral shrine from Zhu Xi's

Zhuzi Jiali.

I.9 The offering hall in the living quarters, with an ancestral shrine in the upper left, in Xidi village, Yixian (Qing).

4.I Unfilial son Zhao is being judged in the first hall of Hell.

4.2 The Forest of Swords in Hell.

4.3 The ten-thousand-pound Copper Mill in Hell.

4.4 The Bed of Nails in Hell.

4.5 The Lake of Blood in Hell. 
4.6 The Cauldron of Oil in Hell.

4.7 The Mirror of Karma in Hell.

4.8 The Looking Home Terrace (wangxiang tai).

4.9 The original cover design for Zheng Zhizhen's script (ca. I 582).

5.I The main hall of the female shrine of the Tangyue Baos, Shexian (Qing).

5.2 The side-facing door of the female shrine of the Tangyue Baos, Shexian (Qing).

5.3 The Treading-Fortune Hall (Lüfu tang) in Xidi village, Yixian (Qing).

5.4 The Auspicious Jade Hall (Ruiyu ting) in Xidi village, Yixian (Qing).

6.I A three-tiered stage in the county seat of Yixian (early nineteenth century). Photograph 1927.

\section{Tables}

2.I Chaste and Martyred Widows in Shexian

5.I Various Categories of Virtuous Women in Huizhou

5.2 Virtuous Women and Huizhou Lineage-Dominated Communities 